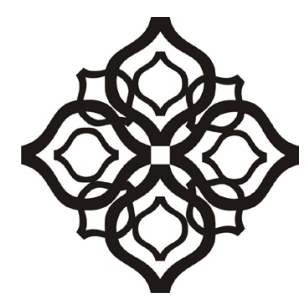

Shirkah

Journal of Economics and Business 


\section{Shirkah}

Journal of Economics and Business

Vol. 3, No. 2, May-August 2018

ISSN: 2503-4235 (p); 2503-4243 (e)

\section{Editor in Chief}

Dwi Condro Triono

\section{Managing Editor}

Jasanta Peranginangin

\section{Editorial Boards}

Abdul Azim Islahi,

Islamic Economics Institute, King Abdulaziz University, Saudi Arabia

Abu Umar Faruq Ahmad,

UBD School of Business and Economics Universiti, Brunei Darussalam

Cedomir Nestorovic,

ESSEC Business School Asia Pacific, Singapore

Fitri Wulandari,

Faculty of Islamic Economics and Business, IAIN Surakarta, Indonesia

Johan Fischer,

Department of Social Sciences and Business Roskilde Universitetscenter, Denmark Muhamed Zulkhibri,

Islamic Research and Training Institute, Islamic Development Bank, Saudi Arabia M. Kabir Hassan,

Department of Economics and Finance, University of New Orleans, United States Musa Asy'arie,

Faculty of Islamic Economics and Business, IAIN Surakarta, Indonesia Nunung Nurul Hidayah,

Aston Business School, Aston University, Birmingham, United Kingdom

Saim Kayadibi,

Department of Economics, Kulliyyah of Economics and Management Science, International Islamic University Malaysia, Malaysia 
Shaikh M Ghazanfar,

Departement of Economics, University of Idaho, Russian Federation

Sigit S. Wibowo,

Department of Management, Faculty of Economics and Business, Universitas Indonesia, Indonesia

Vihang R. Errunza,

Desmarais Global Finance Research Centre, Desautels Faculty and Management, McGill University, Canada

\section{Assistant to Editor}

M. Endy Saputro

M. Zainal Anwar

Shirkah Journal of Economics and Business is a peer-reviewed journal published three times a year (January-April, May-August and September-December) by Faculty of Islamic Economics and Business, Institut Agama Islam Negeri (IAIN) Surakarta Central Java, Indonesia. The main objective of Shirkah is to offer an academic space of exchange ideas and initiate the increase number of qualified article produced by postgraduate students, practitioners and academicians.

\section{Editorial Office}

Ruang Jurnal Shirkah

Lantai Dasar, Sayap Barat, Fakultas Ekonomi dan Bisnis Islam, IAIN Surakarta

Jln. Pandawa No. 1, Kartasura, Sukoharjo, Jawa Tengah Kode Pos. 57168

Phone (+62271) 781516 Fax: (+62271)782336

E-mail: shirkahjournal@iainsurakarta.ac.id; shirkahiainsurakarta@gmail.com Website: http://shirkah.or.id/ 


\section{Shirkah}

\section{Journal of Economics and Business}

Vol. 3, No. 2, May-August 2018

ISSN: 2503-4235 (p); 2503-4243 (e)

\section{Table of Contents}

\section{Articles}

Eko Fajar Cabyono

Lina Nugraha Rani

Macroprudential Policy on Sharia Banking Financing

The Indonesian Experience

Yulianti

Seeing a Buddhist Doing Business in Contemporary Indonesia An Interview with Mr. Sudhamek A.W.S

Fransisca Dwijayanti

Making Economics of Piety

Fashion, Lifestyle and Identity in Pop-Islamism Turn

Indah Piliyanti

Fintech Achieving Sustainable Development

The Side Perspective of Crowdfunding Platform

Taufik Nugroho

Aam S. Rusydiana

Macroeconomic Variables on Indonesian Sharia Capital Market

Hurdle Rate and Adverse Selection on Escalation of Commitment 


\title{
Macroprudential Policy on Sharia Banking Financing The Indonesian Experience
}

\author{
Eko Fajar Cahyono \\ Faculty of Economics and Business, Universitas Airlangga \\ ekofajarc@feb.unair.ac.id \\ Lina Nugraha Rani \\ Faculty of Economics and Business, Universitas Airlangga \\ lina.nugraha@gmail.com
}

\begin{abstract}
The locus of macroprudential policy persuading banks has recently attracted significant attention for such research. Whether and to what extent macroprudential policies established by Bank Indonesia against sharia banks have not researched yet in previous empirical studies. Gathering data during 2008-2016, this article examines the impact of macroprudential policy on credit risk-taking by sharia banks in Indonesia. This research approach uses dynamic panel data analysis technique to investigate the relationship between risk-taking of sharia bank credit and macroprudential policy for a bank in Indonesia good sharia banking. This research shows that there is the influence of Bank Indonesia's macroprudential policy toward murabaha financing in Indonesia.
\end{abstract}

Keywords: macroprudential policy, credit risk, sharia bank.

\section{Introduction}

The global financial crisis has strongly demonstrated a wide spectrum of adverse consequences for the global economics derived from an uncontrolled systemic risk of the banking system. The systemic risk would have increased along with financial vulnerability, such as credit booms, strong dependence on wholesale funds and non-capital-denominated loans at foreign currency (Abedifar, Molyneux, \& Tarazi, 2013). At the same 
time, international capital flows and especially international bank flows, provide a key link in the transmission of systemic risk across countries. Facing these challenges, policymakers across the globe have invested enormous resources in devising policies that not only reduce vulnerability domestic finance but also limits the spread of such vulnerability across the country. This policy is known as macroprudential policy (MPPs) (Beirne \& Friedrich, 2017).

Since the global financial crisis, macroprudential housing finance tools have been increasingly used to reduce the financial system vulnerability associated with housing market imbalances. For example, many countries in Europe, Asia, and America responded to the imbalance in their domestic housing market, partly by tightening credit lines (Cerutti, Dagher, \& Dell'Ariccia, 2017). Although its application is broad-based, the effectiveness of the policy is not well understood. Some tries to fill this gap by analyzing loan rate data on the first home buyer mortgage option (FTHB) in Canada during the period of change of macroprudential regulations (Qudraty \& Suriani, 2017). To quantify the aggregate impact of macroprudential policies on borrower behavior and the dynamic response of total credit, experts propose, calibrate, and apply hypothec demand apocalypse models (Allen et al., 2017).

In Indonesia a macroprudential policy have been implemented by Bank Indonesia. Bank Indonesia (BI) has been the central bank of Indonesia which has full autonomy in formulating and executing each of its duties and authorities as stipulated in Law no. 3 of 2004. Bank Indonesia is a state institution having the authority to issue legal means of payment from a country, formulating and implementing monetary policy, regulating and maintaining the smoothness of the payment system, regulating and supervising banks and performing functions as lenders of last resort (Qudraty \& Suriani, 2017). Pressure on macroeconomic stability 
in Indonesia, from 1997 to 1998, to financial institutions and financial markets have a significant impact on the economics of 51 percent of national income. Crises have led to macro policy failures, market failures, and regulatory failures.

As the country with the largest Muslim population in Indonesia, the development of Islamic banks is undeniable. The Islamic banks are present to meet the aspirations of Muslims in driving economic and banking transactions based on Islamic law (Aliyu, Hassan, Yusof, \& Naiimi, 2017). As an inseparable part of the stability of the financial system, Islamic banks also exposed to the risk of financial interconnection that is the risk of experiencing paralysis due to the collapse of other financial institutions that have networks with sharia banks. This risk is called systemic risk. It is necessary compare the Indonesian case to other countries precedence, such as Jiménez, et.al (2017) that observe the dynamics of reserve requirements which enabled Spain to successfully overcome the credit cycle and avoid the impact of contraction on the real economics. Igan and Kang (2011) provide evidence supporting the fact that debt-for-income (DTI) and LTV ratios are successful in controlling rising house prices in Korea. The evidence for Hong Kong also proves the efficacy of the LTV ratio (Craig \& Hua, 2011). In the case of Croatia, Kraft \& Galac (2011) investigate how a strong inflow of capital hit the macroprudential response and thus reduced the ferocity of the financial crisis in the domestic banks. It is happened also in both the Estonian experience (Sutt, et al, 2011) and Turkey (Kenc, Turhan, \& Yildrim, 2011).

This article questions the effect of Bank Indonesia prudential macro policy on the behavior of risk making o housing credit in Indonesia represented by two questions as follows, focusing on what is the effect of Bank Indonesia's mandatory minimum reserve requirement on murabaha scheme financing of sharia banks in Indonesia and what is the effect of the loan to value and loan to deposit ratio policy on the same scheme. 


\section{Quantitative Approaches}

This article has brought quantitative approach. Quantitative approach is a research approach that primarily uses certain paradigm (such as thinking about causality, reduction to variables, hypotheses, and specific questions, using measurement and observation, and theory testing) in developing scientific theory, using strategies such as experiments and surveys requiring statistical data. In this approach, there are several forms of research: first, correlational research/survey is a general approach to research that focuses on assessing the co-variation between naturally occurring variables. The goal is to identify predictive relationships using more sophisticated correlation techniques or statistical techniques (Empire, 2007 , p. 37). Type of research approach is explanatory research, seeking to investigate the relationship between variables.

The object of research is the amount of financing with murabaha scheme done by sharia banking in Indonesia and macroprudential policy which stipulated by Bank Indonesia that comprised of the policy of determination of reserve requirement and loan to value (Bian, Lin, \& Liu, 2018). The data is secondary data. Secondary data is data taken indirectly or through the document of institution or institution document. The data gathered from the document of Bank Indonesia as the central bank and the document of the Financial Services Authority as the regulator of sharia banking in Indonesia. Variable in this research divided into two, namely dependent variable and independent variable. The dependent variable in this study is the total amount of sharia bank financing by using murabaha scheme (Syafi'i, 2012). The independent variables in this article are macroprudential policies stipulated by Bank Indonesia such as minimum reserve requirement, loan to value and loan to deposit ratio.

Sharia bank financing data in Indonesia in annual form from 2006 to 2016 , the statutory minimum reserve requirement data is taken from 
2006 to 2016 and loan to value and loan to deposit ratio policy data in the form of annual data from 2010 to 2016 (Al-Salim, 2009). Answering both questions on problem formulation; this study used two different analytical models for each question. The first question answered by the time series regression analysis model for reasons of data availability. GWM data and sharia bank financing in Indonesia are available from 2006 to 2016 so that this data is said to be feasible to be analyzed using time series data. Answering the question on the formulation of the second problem; this research uses multiple linear regression analysis models. This decision was taken because insufficient data were used for the time series data and to answer the second question the formulation of the second problem used multiple linear regression analysis.

\section{Analyzing the Models}

Table. 1 ADF Test

\begin{tabular}{|l|l|l|l|l|}
\hline \multicolumn{1}{|c|}{ Variable } & \multicolumn{1}{|c|}{ ADF t Statistics } & \multicolumn{1}{c|}{$\begin{array}{c}\text { McKinnon } \\
\text { Critical value 5\% }\end{array}$} & Probability & Information \\
\hline \multicolumn{5}{|c|}{ Testing at the level level } \\
\hline GWM & -1.671339 & -2.931404 & 0.4383 & Not Stationary \\
\hline P_Murabahah & -0.419080 & -2.935001 & 0.8963 & Not Stationary \\
\hline \multicolumn{5}{|c|}{ Testing at the first level of differentiation } \\
\hline DGWM & -6.591251 & -2.933158 & 0.0000 & Stationary \\
\hline DP_Murabahah & -3.671385 & -2.933158 & 0.0082 & Stationary \\
\hline
\end{tabular}

From the table above can be seen if the variable GWM and $\mathrm{P}_{-}$ murabaha not stationary at the level because of the value of McKinnon value $5 \%<$ ADF t-statistics (-2.931404<-1.671339/ -2.935001<-0.419080). $\mathrm{H} 0$ is accepted, and $\mathrm{H} 1$ rejected, in other words, both data in each variable is not stationary. Meanwhile, in testing at the first differentiation level, the two variables (GWM and P_murabaha) 1 are both stationary. The table 
indicated by the value at McKinnon value 5\% > ADF t-statistics on each variable. As in the variable GWM is $-2.933158>-6.591251$ and variable P_murabaha is $-2.933158>-3.671385$. H0 is rejected, and H1 is accepted.

Table 2. Test Lag Length Criteria

\begin{tabular}{ccccccc}
\hline \hline Lag & LogL & LR & FPE & AIC & SC & HQ \\
\hline \hline 0 & -388.4702 & NA & 1032792. & 19.52351 & $19.60795^{\star}$ & 19.55404 \\
1 & -382.2652 & $11.47933^{*}$ & $925480.3^{*}$ & $19.41326^{*}$ & 19.66659 & $19.50485^{\star}$ \\
2 & -379.1699 & 5.416763 & 970307.1 & 19.45849 & 19.88071 & 19.61115 \\
3 & -377.9251 & 2.053908 & 1118814. & 19.59625 & 20.18736 & 19.80998 \\
\hline \hline
\end{tabular}

The table above shows if the lag one as the optimal lag because of the above test results shows the most stars is in lag 1 .

Table 3. Cointegration Test

\begin{tabular}{ccccc}
\hline \hline $\begin{array}{c}\text { Hypothesized } \\
\text { No. of CE }(\mathrm{s})\end{array}$ & Eigenvalue & $\begin{array}{c}\text { Trace } \\
\text { Statistic }\end{array}$ & $\begin{array}{c}0.05 \\
\text { Critical Value }\end{array}$ & Prob. $^{\star \star}$ \\
\hline \hline None & 1.000000 & NA & 15.49471 & NA \\
At most $1{ }^{*}$ & 0.332508 & 16.57332 & 3.841466 & 0.0000 \\
\hline \hline
\end{tabular}

From the table above, it can explain that in the 5\% test level $(0$, $05)$, there are three rank variables related to co-integration. It can prove from the trace statistic value 16.57332 greater than critical value 0.05 , i.e., 3.841466 which means $\mathrm{H} 0$ rejected and $\mathrm{H} 1$ accepted or in other words, the variables used have a long-term relationship (co-integration) with each other. Therefore, VECM estimates in this article can be used. Furthermore, the VECM stability test can perform. The negative co-integration value indicates error correction in the previous year model. 
Table 4. Estimated VECM model

\begin{tabular}{|c|l|l|}
\hline Variables & \multicolumn{1}{|c|}{ Coefficient } & t-Partial Statistics \\
\hline P_Murabahah & $-0,00000614$ & -0.39330 \\
\hline
\end{tabular}

From the VECM estimation table in the short term above, it can be explained that the variable $\mathrm{P} \_$murabahain lag 1 has a negative and significant effect on the exchange rate of $-0,00000614$. The negative relationship can be seen from the coefficient while the signification relationship can be seen from the partial t-statistic value, if the partial t-statistic value is lower than 1,96 then the value is said to be significant. That is, if there is an increase of the statutory reserve requirement amounting to one unit in the previous year, it will increase the murabaha financing rate in the current year by 0 , 00000614.

Table 5. Increased VECM model

\begin{tabular}{|c|l|l|}
\hline Variables & \multicolumn{1}{|c|}{ Coefficient } & \multicolumn{1}{c|}{ t-Partial Statistics } \\
\hline P_Murabahah & $-0,00000121$ & -0.72700 \\
\hline
\end{tabular}

Meanwhile, to see a long-term relationship as well as to see the value of short-term relationship table above shows a negative and significant relationship. It can be seen in more detail the results of VECM estimation in the section of appendix below. 
Graphics 1. Impulse Response Analysis

Response of DGWM to DP_MURABAHAH

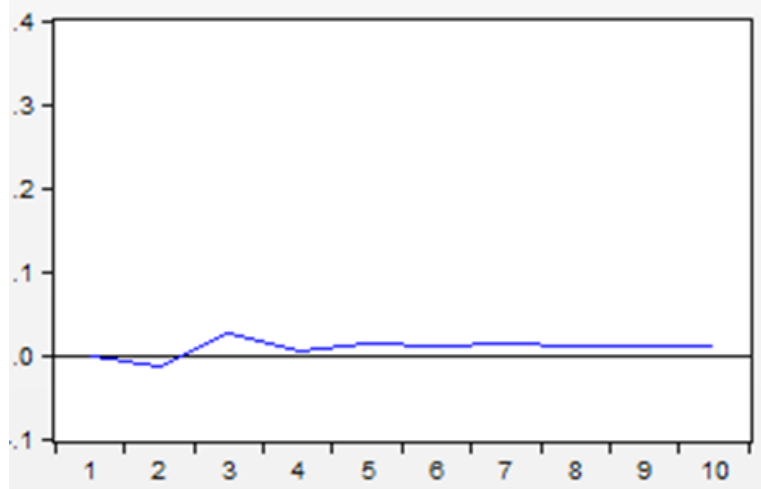

The impulse response analysis shows the shock rate of the variables used in the study. Impulse Response Function gives an overview of how the response of a variable in the future if there is interference with one other variable. The results of the analysis presented in the graphic form below in 10 periods. GWM response to shock P_murabaha in the first and second period tends to experience a negative trend. The result can see from the IRF line that is below the horizontal line. In the third period, it increased positively and tended to stabilize in the next period until the tenth period.

\section{Table 6. DP-murabaha}

\begin{tabular}{|c|c|c|c|}
\hline \multicolumn{4}{|c|}{ Variance Decomposition of DGWM: } \\
\hline Period & S.E. & DGWM & DP_MURABA... \\
\hline 1 & 0.320645 & 100.0000 & 0.000000 \\
\hline 2 & 0.321406 & 99.79803 & 0.201971 \\
\hline 3 & 0.323005 & 99.10278 & 0.897223 \\
\hline 4 & 0.323058 & 99.07556 & 0.924438 \\
\hline 5 & 0.323408 & 98.87764 & 1.122358 \\
\hline 6 & 0.323583 & 98.77414 & 1.225858 \\
\hline 7 & 0.323829 & 98.63199 & 1.368008 \\
\hline 8 & 0.324041 & 98.50873 & 1.491271 \\
\hline 9 & 0.324268 & 98.37758 & 1.622416 \\
\hline 10 & 0.324488 & 98.25055 & 1.749451 \\
\hline
\end{tabular}

Vol. 3 No. 2, May - August 2018 
The results of VDC analysis can see in the table above. The Variance Decomposition Model is used to provide a detailed explanation of how a single variable change is affected by changes in other variables. The change in variance error indicates changes that occur in variables. In the first period, the GWM is strongly influenced by the GWM Shock itself by $100 \%$. Meanwhile, in the first period, the P_murabaha variable has not affected the reserve requirement. Then in the second period onwards, the new P_murabaha variable affects the reserve requirement. Suppose the second period contributes $0,2 \%$ and so on in the next period.

Equation : VECM estimation with GWM as dependent variable:

$$
\begin{aligned}
\Delta D G W M t=- & 1.12461 \operatorname{ect}_{(t-1)}+0.08161 \Delta D G W M_{(t-1)} \\
& -(-0.00001) \Delta D P_{-} M U R A B A H A H_{(t-1)}
\end{aligned}
$$

Cointegration equation, long-term model:

ect $_{(t-1)}=1.000000$ DGWM $_{(t-1)}-0.000006 P_{-}$MURABAHAH $_{(t-1)}+0.082476$

\section{Explaining the Second Problem Formulation}

\section{Table 7. LTV Treadmill Type 1}

\begin{tabular}{|ll|r|r|}
\hline & \multicolumn{1}{|c|}{$\begin{array}{c}\text { Murabahah } \\
\text { financing }\end{array}$} & $\begin{array}{c}\text { Treadmill } \\
\text { type 1 }\end{array}$ \\
\hline Murabahah financing & Pearson Correlation & 1 & -.608 \\
& Sig. (2-tailed) & 10 & .062 \\
& $\mathrm{~N}$ & -.608 & 10 \\
\hline Treadmill type 1 & Pearson Correlation & .062 & 1 \\
& Sig. (2-tailed) & 10 & 10 \\
\hline
\end{tabular}


From the above correlation analysis results, it shows that LTV type 1 home tread does not have a close correlation with murabaha financing. Table indicated by the significance value (2-tailed) of 0.062 , greater than $\alpha$ $5 \%(0,05)$. The value of Pearson correlation coefficient shows the number -0.608. Thus, the closeness of the relationship between LTV type 1 home and murabaha financing is a medium category and has a direction of relationship inversely.

Table 8. LTV Treadmill Type 2

\begin{tabular}{|ll|r|r|}
\hline & & $\begin{array}{c}\text { Murabahah } \\
\text { financing }\end{array}$ & $\begin{array}{c}\text { House } \\
\text { footprint type } \\
2\end{array}$ \\
\hline Murabahah financing & Pearson Correlation & 1 & -660 \\
& Sig. (2-tailed) & & .038 \\
& $\mathrm{~N}$ & 10 & 10 \\
\hline House footprint type 22 & Pearson Correlation & $-660^{*}$ & 1 \\
& Sig. (2-tailed) & .038 & 10 \\
& $\mathrm{~N}$ & 10 & \\
\hline
\end{tabular}

*. Correlation is significant at the 0.05 level (2-tailed).

The results of the above analyses indicate that LTV type 2 home footprints and murabaha financing have a close correlation. Table indicated by the value of significance (2-tailed) of 0.038 , smaller than a 5\% $(0,05)$. Pearson correlation coefficient value of -0.660 , indicating that LTV type 2 home footprint and murabaha financing has a strong correlation and the direction of the relationship between the two is inversely proportional. The direction of this inverse relationship has consequences if the LTV ratio of type 2 home sites has increased, so murabaha financing disbursed by sharia banks has decreased. Conversely, when the LTV ratio of type 2 home sites has decreased, the murabaha financing channeled by sharia banks has increased. 
Table 9. LTV Type 3 Households

\begin{tabular}{|ll|r|r|}
\hline & & $\begin{array}{c}\text { murabaha } \\
\text { financing }\end{array}$ & $\begin{array}{c}\text { House } \\
\text { footprint type } \\
3\end{array}$ \\
\hline Murabaha financing & Pearson Correlation & 1 & $-.749^{*}$ \\
& Sig. (2-tailed) & & .013 \\
& $\mathrm{~N}$ & 10 & 1 \\
\hline House footprint type 3 & Pearson Correlation & $-.749^{*}$ & \\
& Sig. (2-tailed) & .013 & 10 \\
& $\mathrm{~N}$ & 10 & 10 \\
\hline
\end{tabular}

*. Correlation is significant at the 0.05 level (2-tailed).

The results of the above analysis show that LTV type 3 home houses closely correlated with murabaha financing with a significance value (2-tailed) of 0.013 , smaller than a 0,05 . The Pearson correlation coefficient value of -0.749 indicates that LTV type 3 home houses and murabaha financing are strongly correlated and the direction of the relationship between them is inversely proportional. If BI issued a policy to raise the ratio of LTV type 3 home tread, it would have an impact on the reduction of murabaha financing channeled by Islamic banks.

\section{Table 10. Correlations}

\begin{tabular}{|ll|r|r|}
\hline & $\begin{array}{c}\text { murabaha } \\
\text { financing }\end{array}$ & \multicolumn{1}{|c|}{ Type 1 flats } \\
\hline murabaha financing & Pearson Correlation & 1 & -.608 \\
& Sig. (2-tailed) & 10 & .062 \\
& $\mathrm{~N}$ & -.608 & 10 \\
\hline Type 1 flats & Pearson Correlation & .062 & 1 \\
& Sig. (2-tailed) & 10 & 10 \\
& $\mathrm{~N}$ & & \\
\hline
\end{tabular}


The result of the above correlation analysis shows that the LTV of type 1 housing and murabaha financing are not correlated closely. The significance value (2-tailed) shown is 0.062 greater than $\alpha 0,05$ so that both do not have a close correlation. Pearson correlation coefficient value of -0.608 indicates that the direction of the relationship between type 1 flats LTV with murabaha financing is inversely proportional and the closeness of the relationship between the two included in the medium category.

\section{Table 11. Correlations}

\begin{tabular}{|ll|r|r|}
\hline & & $\begin{array}{r}\text { murabaha } \\
\text { financing }\end{array}$ & Flats type 2 \\
\hline Murabaha financing & Pearson Correlation & 1 & $-660^{*}$ \\
& Sig. (2-tailed) & 10 & .018 \\
& $\mathrm{~N}$ & $-660^{*}$ & 10 \\
\hline Flats type 2 & Pearson Correlation & .018 & 1 \\
& Sig. (2-tailed) & 10 & 10 \\
\hline
\end{tabular}

*. Correlation is significant at the 0.05 level (2-tailed).

The result of correlation analysis above shows the significance value (2-tailed) is 0,038 , smaller than a 0,05 so it can be concluded that LTV type 2 flats and murabaha financing are closely correlated. Pearson correlation coefficient value of -0.660 indicates that between type 2 flats LTV with murabaha financing has a strong correlation and the direction of the relationship is inversely proportional. If the type 2 flats LTV has increased, then the amount of murabaha financing disbursed by sharia banks will decrease. 
Table 12. Correlations

\begin{tabular}{|ll|r|r|}
\hline & & $\begin{array}{r}\text { murabaha } \\
\text { financing }\end{array}$ & Flats type 2 \\
\hline Murabaha financing & Pearson Correlation & 1 & $-.749^{*}$ \\
& Sig. (2-tailed) & & .013 \\
& $\mathrm{~N}$ & 10 & 10 \\
\hline Flats type 3 & Pearson Correlation & $-.749^{*}$ & 1 \\
& Sig. (2-tailed) & .013 & 10 \\
\hline
\end{tabular}

*. Correlation is significant at the 0.05 level (2-tailed).

The above analysis results show the significance value (2-tailed) of 0.013 , smaller than a 0.05 so that between the LTV type 3 flats with murabaha financing are closely correlated. The Pearson correlation coefficient value is -0.749 is indicating that the correlation between them has a reversed direction. If BI improves the ratio of type 3 flats LTV, then the amount of murabaha financing disbursed by sharia banks has decreased.

Table 13. Correlations

\begin{tabular}{|ll|r|r|}
\hline & & $\begin{array}{r}\text { murabaha } \\
\text { financing }\end{array}$ & $\begin{array}{c}\text { LDR Upper } \\
\text { limit }\end{array}$ \\
\hline Murabaha financing & Pearson Correlation & 1 & $-.793^{* *}$ \\
& Sig. (2-tailed) & 10 & .006 \\
& $\mathrm{~N}$ & 10 \\
\hline LDR Upper limit & Pearson Correlation & $-.793^{* *}$ & 1 \\
& Sig. (2-tailed) & .006 & 10 \\
\hline
\end{tabular}

**. Correlation is significant at the 0.01 level (2-tailed).

The results of the above correlation analysis indicate that upper limit LDR and murabaha financing have a close correlation. Table 
indicated by the value of significance (2-tailed) of 0.006 , smaller than $a$ 0,05 so that the results are significant at the $5 \%$ level. While the value of Pearson correlation coefficient of -0.793 , indicating that between the two have a strong level of correlation and correlation direction that is inversely proportional. If BI issued a policy to raise the upper limit of the LDR, then it will open more opportunities for banks to channel more financing to customers but the above analysis shows that the upper limit of LDR decreases murabaha financing channeled by sharia banks.

Table 14. Correlations

\begin{tabular}{|ll|r|r|}
\hline & & $\begin{array}{r}\text { murabaha } \\
\text { financing }\end{array}$ & $\begin{array}{c}\text { LDR Lower } \\
\text { limit }\end{array}$ \\
\hline Murabaha financing & Pearson Correlation & 1 & $.661^{*}$ \\
& Sig. (2-tailed) & 10 & .037 \\
& $\mathrm{~N}$ & $.661 *$ & 10 \\
\hline LDR Lower limit & Pearson Correlation & .037 & 1 \\
& Sig. (2-tailed) & 10 & 10 \\
\hline
\end{tabular}

*. Correlation is significant at the 0.05 level (2-tailed).

The result of correlation analysis above shows Pearson correlation coefficient value of 0.661 with significance value (2-tailed) 0,037 . The table indicates that lower LDR and murabaha financing are correlated significantly at the $5 \%$ level. The value of positive correlation coefficient indicates that the direction of correlation between the two is unidirectional. If the lower LDR ratio increases, the murabaha financing channeled by sharia banks also has to be up. This finding should be put in the context of macroprudential history and policies in Indonesia. 


\section{A History of Macroprudential}

According to Kahou \& Lehar (2017), the term "macroprudential” has become a popular term after the recent financial crisis. However, as Clement notes, the term "macroprudential" can be traced back to the late 70 s. One of the main problems currently among financial regulators is the rapid growth of loans in developing the country and its potential negative impact on financial levels. In 1979, the term "macroprudential" was first introduced at a meeting at the Cooke Committee (the predecessor of the Basel Committee on Banking Supervision, BCBS) to deal with the problem of international bank lending. Shortly after fulfilling the term "macroprudential" introduced in a document.

\section{Table 15. Macroprudential and Microprudential}

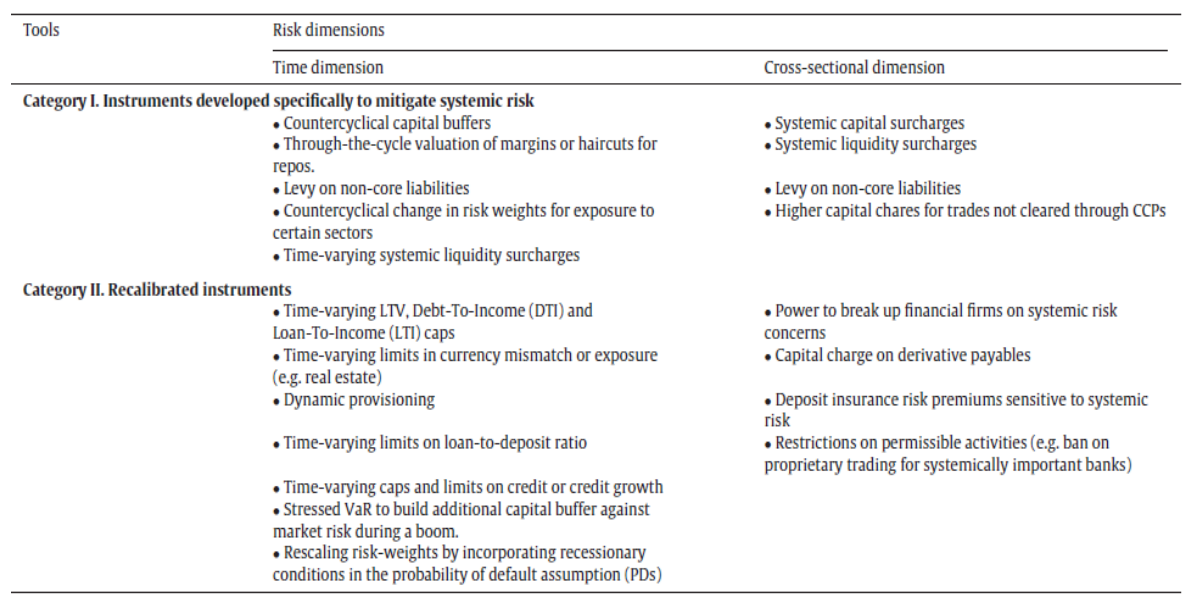

Source: Kahou \& Lehar (2017)

Gosh (2014) reveals that related literature has already classified macroprudential policies into two broad categories: (1) designed to address the procyclicality of the financial system; and (2) focused on handling financial linkage systems. In essence, it reflects the strengthening 
mechanisms that operate within the financial system as well as between the financial system and the real economy (Sarangee, Woolley, Schmidt, \& Long, 2014; Deng \& Cranford, 2018). This mechanism is realized over time and is based on the tendency of economic actors to be very optimistic in progress and thus increase their risk exposure, and then become excessively avoid risk during the bubble phase. The latter, on the other hand, magnifies the impact of financial difficulties. This mechanism depends on the concentration risk (number and size of financial institutions, their substitution, and vulnerability) and systemic linkages (the intra-financial level of system activity) and usually manifested at the time point (the cross-sectional dimension) (Sarangee et al., 2014). It can mention in this context that Indonesia already has some macroprudential policies as part of their regulatory prescriptions. Most of these steps are focused essentially on the time dimension. To give some examples, Indonesia has a loan to deposit ratio (or some variant of it) in place; and Indonesia has standard or interchangeable lending conditions, restrictions on foreign currency exposures, such as in the case of borrowing limits or the case of the bank's net foreign exchange position. Its focus is primarily on macroprudential policies introduced around the crisis.

\section{Macroprudential Policies}

The central bank is the institution that conducts macroprudential policy (regulation and supervision). This macroprudential policy is one of the mandates of the Central Bank in supporting the SSK. The Central Bank also supports SSK through the implementation of monetary policy, payment system, and management of foreign capital flows, including the central bank's authority in regulating and overseeing foreign exchange and money market markets as integral monetary policy (Koedijk, Loungani, \& Monnin, 2018). Regulation and supervision of financial services 
institutions are macro and focused on systemic risk within to encourage SSK (Agustin, 2016). The main objective is to mitigate risks arising from the procyclicality of macro-financial linkages as well as the accumulation of systemic risks arising from interconnection and networking among institutions, markets, and financial infrastructure including payment systems (Lok, 2015). Prevent the accumulation of risks from the boombust of the financial cycle due to factors of the financial system as well as its interaction with the domestic and international economy (time series) which is the main target of macroprudential policy (Crowe, et al., 2013). The second objective of the macroprudential policy is to strengthen financial system resilience and mitigate the risk of awakening from the interconnection and networking of the financial system (cross-sector dimensions) (Ahmad, 2017). Both of these goals, macro perspectives and focus on systemic risk in SSK, are different from regulatory goals and macroprudential surveillance to maintain the health of individual financial institutions (Warjiyo and Juhro, 2016).

In contrast to the cases, Warjiyo and Juhro (2016) highlight PPKS Act as "Systemic Bank" is defined a Bank due to the size of assets, capital and liabilities. Whether operational or financial, if the Bank is impaired or fails. The Bank's failure has an impact on systemic risk on the failure of the financial system as a whole (Mahlendorf, 2015). The PPKSP Law stipulates that systemic banks are required to comply with special provisions concerning the capital adequacy ratio and the adequacy of liquidity ratio. As well as to prepare an action plan that contains at least the obligations of the controlling shareholders and other parties to increase bank capital and convert certain types of debt to bank capital (Fareed, Arsalan, \& Ayubi, 2017; Abdul-Rahman, 2014).

Wajiyo and Juhro (2016) mentions ten macroprudential policy instruments that can be applied that include instruments for procedural 
control and systemic risk associated with credit exposure, foreign exchange, liquidity, and capital. For loan procurement, a general instrument used is loan-to-value (LTV), debt-to-income (DTI), and restrictions on credit growth in certain sectors (Morgan, Regis, \& Salike, 2019). Foreign exchange exposure, the instrument includes the net open position (NOP), limits on foreign currency loan, or hedging arrangements regarding obligate (begging) and term foreign debt. Liquidity instruments, Minimum Statutory Reserves (GWM) generally applied to the extent of adjustable dental conditions of growing liquidity (Fareed et al., 2017). To strengthen capital in the face of systemic prosperity and risks include counter-cyclical capital buffer, provision of bad loans by the dynamics of the risk of credit proliferation, to the arrangement of profit sharing (Clancy \& Collins, 2014).

Warjiyo and Juhro (2016) classify macroprudential instruments according to the type of risk, i.e., leverage credit boom/asset price bubble, liquidity/market risk, and interconnection/market structure risk, dynamically anthropically or statically between sectors. Macroprudential instruments may be loosened or tightened by the anticipated risks levels of probable proliferation and systemic risk (Beirne \& Friedrich, 2017). While the capital by the Financial Stability Board (FSB) November 2015 which sets the minimum amount of Total Loss Absorbency Capacity (TLAC) for Global Systemically Important Banks (G-SIBs). The magnitude of the TLAC is to ensure that G-SIBs have sufficient capital to absorb the losses and recapitalization capacity so that if a business resolution or failure occurs, the critical functions of the bank in question can continue without causing any burden on the country and endangering the SSK. TLAC is set at $16 \%$ to $20 \%$ for capital requirements based on weighted risk assets and $6 \%$ to $6.75 \%$ for capital requirements based on the measurement of total bank exposure. The rule applies to G-SIBs set before 2015 (Ghosh, 2016). 
Warjiyo and Juhro (2016) discuss macroprudential policies adopted in several Asian countries, such as China. It is a country with many macroprudential policies among Asian countries over the period of 2000-2013. Simultaneous macroprudential instruments have been implemented in the period 2006-2008, both the People's Bank of China and the China Banking Regulatory Commission to strengthen the SSK. From the macroprudential tightening of credit obtained the result that the policy can control credit expansion (Frost \& van Stralen, 2018). Some macroprudential instruments have also been implemented in South Korea before the 1997/98 global financial crisis and even since the 1997/98 Asian financial crisis (Ghosh, 2016). Some liquidity ratio regulation overcomes the weaknesses of the banking system and foreign valutas transactions (Aliyu, Yusof, \& Naiimi, 2017). The policy is also issued to limit the position of bank foreign exchange derivatives, foreign currency loan provisioning, and tougher liquidity ratios against domestic banks (Misnan, Hee, \& Rizal, 2018). The effect of such tightening is faster than the slowing of credit expansion and leverage increase (Bian et al., 2018).

The implementation of macroprudential policy in India implemented since 2004 through some instruments, including liquidity instruments and capital to maintain SSK. The main focus is on high credit expansion in housing. Also, the macroprudential policy adopted by RBI focuses on banking through countercyclical capital buffer instruments (Kahou \& Lehar, 2017). Macroprudential instruments are also used by RBI liquidity, especially with the increase in the reserve requirement (Bianchi $\&$ Mendoza, 2018). Macroprudential policies in India can control excessive leverage and price increases in the housing sector. In Singapore state, strict monitoring is done by Monetary Authority of Singapore (MAS) to financial system and risk to SSK. MAS respond rapidly to the impact of systemic risk and increased credit exposure by strengthening surveillance 
and assessment of SSCs as well as the necessary policies. In addition to these countries, the macroprudential policy also applied in other Asian countries such as Hong Kong, Malaysia, the Philippines, Thailand, and Indonesia. The implementation of the policy proved to be capable and generally for systemic risk mitigation to maintain SSKs due to rapid credit expansion and high price increases in the housing sector (Warjiyo and Juhro, 2016).

\section{Conclusion}

The result of the research shows that there is the influence of Bank Indonesia's macroprudential policy toward murabaha financing in Indonesia. The result evidenced by the two models of analysis in the study. The first model of analysis using the VECM model shows that the minimum mandatory reserve policy affects the murabaha financing of sharia banks in Indonesia. The second model of analysis indicates that there is an influence of $\mathrm{LtV}$ and LDR policies stipulated by Bank Indonesia on sharia bank financing, defining $\mathrm{Y}=-0.608 \mathrm{X} 1-0.660 \mathrm{X} 2-0.749 \mathrm{X} 3-$ $0.608 X 4-0.660 X 5-0.749 X 6-0.793 X 7+0.661 X 8$. 


\section{References}

Abdul-Rahman, Y. (2014). The Art of RF (Riba-Free) Islamic Banking and Finance: Tools and Techniques for Community-Based Banking. John Wiley \& Sons.

Abedifar, P., Molyneux, P., \& Tarazi, A. (2013). Risk in islamic banking. Review of Finance, 17(6), 2035-2096. https://doi.org/10.1093/rof/ rfs041.

Agustin, H. (2016). Financial performance Islamic banking unit in Indonesia: A comparative study private banks and regional development banks. International Journal of Economic Research, 13(4), 1399-1409.

Ahmad, A. Y. (2017). The role of money in Financial Instability and possibilities of reformation within an Islamic financial system. Journal of King Abdulaziz University, Islamic Economics, 30(3), 187-208. https://doi.org/10.4197/Islec.30-3.7.

Aliyu, S., Hassan, M. K., Mohd Yusof, R., \& Naiimi, N. (2017). Islamic Banking Sustainability: A Review of Literature and Directions for Future Research. Emerging Markets Finance and Trade, 53(2), 440470. https://doi.org/10.1080/1540496X.2016.1262761.

Aliyu, S., Yusof, R. M., \& Naiimi, N. (2017). The role of moral transaction mode for sustainability of banking business: A proposed conceptual model for Islamic microfinance banks in Nigeria. International Journal of Social Economics, 44(12), 2238-2256. https://doi.org/10.1108/ IJSE-07-2016-0205.

Allen J, et al. (2017). The impact of macroprudential housing finance tools in Canada. Journal of Financial Intermediation. https://doi. org/10.1016/j.jfi.2017.08.004

Al-Salim, F. H. (2009). Islamic Financial Product Innovation. International Journal of Islamic and Middle Eastern Finance and Management. Vol. 
2 Issue: 3, 187-200, https://doi.org/10.1108/17538390910986326

Beirne, J., \& Friedrich, C. (2017). Macroprudential policies, capital flows, and the structure of the banking sector. Journal of International Money and Finance, 75, 47-68. https://doi.org/10.1016/j. jimonfin.2017.04.004.

Bian, X., Lin, Z., \& Liu, Y. (2018). House price, loan-to-value ratio and credit risk. Journal of Banking and Finance, 92, 1-12. https://doi. org/10.1016/j.jbankfin.2018.04.006.

Bianchi, J., \& Mendoza, E. G. (2018). Optimal time-consistent macroprudential policy. Journal of Political Economy, 126(2), 588634. https://doi.org/10.1086/696280.

Cerutti, E., Dagher, J., \& Dell'Ariccia, G. (2017). Housing finance and real-estate booms: a cross-country perspective. Journal of Housing Economics. Volume 38, 1-13. https://doi.org/10.1016/j. jhe.2017.02.001.

Clancy, D. K., \& Collins, D. (2014). Capital budgeting research and practice: The state of the art (Vol. 24). https://doi.org/10.1108/S1474787120140000024004.

Craig, R., \& Hua, C. (2011). Determinants of property prices in Hong Kong SAR: Implications for policy. Working Paper No. 11/277. Retrieved from https://www.imf.org/en/Publications/WP/Issues/2016/12/31/ Determinants-of-Property-Prices-in-Hong-Kong-SAR-Implicationsfor-Policy-25389, March $6^{\text {th }} 2018$.

Crowe, et al. (2013). How to deal with real estate booms: Lessons from country experiences. 300-319. Journal of Financial Stability, 9(3), 300-319. https://doi.org/10.1016/j.jfs.2013.05.003.

Deng, Y., \& Cranford, S. W. (2018). Tunable toughness of model fibers with bio-inspired progressive uncoiling via sacrificial bonds and hidden length. Journal of Applied Mechanics, Transactions ASME, 85(11). https://doi.org/10.1115/1.4040646. 
Fareed, S., Arsalan, T., \& Ayubi, S. (2017). Bank deals with liquidity: The micro and macroeconomic determinants approach evidence from Pakistan (Vol. 2017-January, pp. 1073-1086). Presented at the Proceedings of the 30th International Business Information Management Association Conference, IBIMA 2017 - Vision 2020: Sustainable Economic development, Innovation Management, and Global Growth.

Frost, J., \& van Stralen, R. (2018). Macroprudential policy and income inequality. Journal of International Money and Finance, 85, 278-290. https://doi.org/10.1016/j.jimonfin.2017.11. 010.

Ghosh, S. (2016). Macroprudential policies, crisis and risk-taking: Evidence from dual banking systems in GCC countries. Journal of Islamic Accounting and Business Research, 7(1), 6-27. https://doi. org/10.1108/JIABR-03-2014-0011.

Igan, D., \& Kang, H. (2011). Do loan-to-value and debt-to-income limits work? Evidence from Korea.

Jiménez, et.al. (2017). Macroprudential policy, countercyclical bank capital buffers and credit supply: Evidence from the Spanish dynamic provisioning experiments. Journal of Political Economy 125, no. 6, 2126-2177. https://doi.org/10.1086/694289

Kahou, M., \& Lehar, A. (2017). Macroprudential policy: A review. Journal of Financial Stability, 29, 92-105. https://doi.org/10.1016/j. jfs.2016.12.005.

Kenc, T., Turhan, M., \& Yildrim, O. (2011). The experience with the macro-prudential policies of the central bank of the republic of Turkey in response to the global financial crisis. Policy Research Working Paper. https://doi.org/10.1596/1813-9450-5834.

Koedijk, K. G., Loungani, P., \& Monnin, P. (2018). Monetary policy, macroprudential regulation and inequality: An introduction to the special section. Journal of International Money and Finance, 85, 163167. https://doi.org/10.1016/j.jimonfin.2017.11.003. 
Kraft, E., \& Galac, T. (2011). Macroprudential regulation of credit booms and busts - the case of Croatia: The World Bank. Policy Research working paper; no. WPS 5772. Washington, DC: World Bank.

http://documents.worldbank.org/curated/en/438101468232747295/ Macroprudential-regulation-of-credit-booms-and-busts-the-case-ofCroatia

Lok, C. K. (2015). Adoption of smart cardbased E-payment system for retailing in Hong Kong using an extended technology acceptance model (Vol. 23B). https://doi.org/10.1108/S1069-09642015000023B003.

M. Syafi'I, A. (2012). Bank Syariah dari Teori ke Praktik. Jakarta: Gema Insani Press.

Mahlendorf, M. D. (2015). Allowance for failure: reducing dysfunctional behavior by innovating accountability practices. Journal of Management and Governance, 19(3), 655-686. https://doi.org/10.1007/s10997013-9276-3.

Misnan, M. B., Hee, O. C., \& Rizal, A. M. (2018). Foreign consumers purchasing intention towards halal product in Malaysia. International Journal of Engineering and Technology(UAE), 7(4), 299-304. https:// doi.org/10.14419/ijet.v7i4.28.22600.

Morgan, P. J., Regis, P. J., \& Salike, N. (2019). LTV policy as a macroprudential tool and its effects on residential mortgage loans. Journal of Financial Intermediation, 37, 89-103. https://doi. org/10.1016/j.jfi.2018.10.001.

Qudraty, M., \& Suriani, S. (2017). Effectiveness of makroprudensi policy banking and distribution of credit in Aceh. Journal of Economic Perspectives Darussalam, 2(1), 32-53.

Sarangee, K. R., Woolley, J. L., Schmidt, J. B., \& Long, E. (2014). Deescalation mechanisms in high-technology product innovation. Journal of Product Innovation Management, 31(5), 1023-1038. https://doi.org/10.1111/jpim.12142. 
Sutt, et al. (2011). The role of macro-prudential policies in the boom and adjustment phase of the credit cycle in Estonia. Policy Research working paper ; no. WPS 5835. Washington, DC: World Bank. http://documents. worldbank.org/curated/en/471931468246912942/The-role-of-macroprudential-policies-in-the-boom-and-adjustment-phase-of-the-creditcycle-in-Estonia. 


\section{Shirkah Author Guidelines}

Shirkah currently offers two routes to submit manuscripts. We highly recommend to submit the articles which are made using OJS (Open Journal System). Feel free register as author soon through visiting http:// shirkah.or.id/index.php/home/user/register. The authors may directly send their manuscripts, along with their resume, to shirkahiainsurakarta@ gmail.com. Please prepare your manuscripts, using following guidelines:

1. Manuscript must be written in English. Submitted articles should not have been published or be under review for publication with another journal.

2. Manuscript's length is about $15-20$ pages, typed in one-half spaced on A4-paper size.

3. Manuscript must include an $150-200$ word abstract and keywords.

4. Manuscript must be arranged as follows: Title, Name of Author, E-mail address, Abstract, Keywords, Introduction (including method if any), Discussion, Conclusion, References.

5. Manuscript's titles not more than ten words.

6. Manuscript must be submitted in Microsoft Word or RTF.

7. Arabic words should be transliterated according to the style of International Journal of Middle Eastern Studies.

8. Manuscript references are preferably derived from the up-to-date references.

9. The author's resume should be submitted separately, consisting of at least full name, institutional address, phone number, areas of studies, and recent publications (if any).

10. Shirkab use APA Style 6th edition (2010) as reference format writing. We suggest the use of a reference manager software such as Mendeley, Zotero, and Endnote at templating the citation style. APA Style to be used is as follows: 


\section{Book with single author}

Swann, G. M. Peter. (2014). The Economics of Innovation an Introduction. Cheltenhum \& Northampton: Edward Elgar.

in-text citation: (Swann, 2014)

\section{Articles in reference books}

Alatas, S. F. (2006). Islam and the Science of Economics in Abu Rabi', I.M. The Blackwell Companion to Contemporary Islamic Thought. USA: Willey-Blackwell (pp. 587-606).

in text citation: (Alatas, 2006)

\section{E-Book}

Hackett, Rosalind (2007). "Religous Dimentions of War and Peace: Introduction.” Dalam Gerrie ter Haar dan Yoshio Tsuruoka (Ed.), Religion and Society: An Agenda for the 21st Century (h. 3-6). Retrieved from http:// brill.nl.

in text citation: (Hackett, 2006)

\section{Master's thesis, from a commercial database}

McNieI, D. S. (2006). Meaning through narrative: A personal narrative discussing growing up with an alcoholic mother (Master's thesis). Available from ProQuest Dissertations and Theses database. (UMI No. 1434728)

in text citation: (Mc Niel, 2006)

\section{Doctoral dissertation, from an institutional database}

Adams, R. J. (1973). Building a foundation for evaluation of instruction in higher education and continuing education (Doctoral dissertation). Retrieved from http://www.ohiolink.edu/etd/

in text citation: (Adams, 1973) 


\section{Doctoral dissertation, from the web}

Bruckman, A. (1997). MOOSE Crossing: Construction, community, and learning in a networked virtual world for kids (Doctoral dissertation, Massachusetts Institute of Technology). Retrieved from http:/www-static. cc.gatech.edu/--asb/thesis/

in text citation: (Bruckman, 1997)

\section{Journal article with No DOI}

Bourkhis, K., and Nabi, M. S. (2013). Islamic and conventional banks' soundness during the 2007-2008 financial crisis. Journal Metrics, 22(2), 68-77.

in-text citation: (Bourkhis \& Nabi, 2013).

\section{Journal article with DOI}

Ichwan, M. (2012). The Local Politics Of Orthodoxy: The Majelis Ulama Indonesia in the Post-New Order Banten. Journal Of Indonesian Islam, 6(1), 166-194. doi:http://dx.doi.org/10.15642/JIIS.2012.6.1.166-194

In text citation : (Ichwan, 2012)

\section{Abstract as citation}

Hasan, N. (2012). Islamist Party, Electoral Politics And Da'wah Mobilization Among Youth : The Prosperous Justice Party (PKS) in Indonesia. Journal of Indonesian Islam, 6(1), 17-47. Abstract from http:// jiis.uinsby.ac.id/index.php/jiis/article/view/97

in text citation : (Hasan, 2012)

\section{Mass media article}

Sahal, Akhmad (2014, March 2). Kiai Sahal dan Realisme Fikih.Tempo Magazine, p. 120.

in text citation : (Sahal, 2014) 


\section{Research report}

Fisher, B. S., Cullen, F. T., \& Turner, M. G. (2000). The Sexual Victimization of College Women. Research Report.

in text citation : (Fisher, Cullen, Turner, 2000)

\section{Monograph}

Routray, Bibhu Prasad (2013), National Security Decision-Making in India (RSIS Monograph No. 27). Singapura: Rajaratnam School of International Studies.

in text citation : (Routray, 2013)

\section{Proceeding article}

Sudibyakto, Hizbaron, D.R., \& Jati, R (Ed.) (2009), Proceeding International Seminar Disaster Theory, Research and Policy. International seminar held by Sekolah Pascasarjana, Universitas Gajahmada, Yogyakarta, 8-9 Desember 2009.

in text citation : (sudibyakto and Jati, 2009)

\section{Paper conference/seminar/symposium}

Janutama, Herman Sinung (2011). "Kraton dan Hubungan Antar Agama." Paper presented in Seminar Kraton dan Panatagama held by Center for the Study of Islam and Social Transformation (CISForm), Yogyakarta, 17 November.

in text citation :(Janutama, 2011)

\section{Online article in web}

Shiva, (2006, February). Bioethics: A Third World Issue. Native-web. Diperoleh dari http://www.nativeweb.org/ pages/legal/shiva.html

in text citation : (Shiva, 2006) 


\section{Online research report}

Kessy, S. S. A., \& Urio, F M. (2006). The contribution of microfinance institutions to poverty reduction in Tanzania (Research Report No. 06.3). Retrieved from Research on Poverty Alleviation website: http://www. repoa.or.tz /documents_storage/Publications/Reports/06.3_Kessy_and_ Urio.pcif

in text citation : (kessy and urion, 2006)

\section{Holy book}

Qur an, $2(25)$

In text citation : (Q. al-Baqarah 2:25).

\section{Encyclopaedia}

Graycar, Adam (1992). Social Welfare Policy. Dalam Mary Hawkesworth dan Maurice Kogan (Ed.), Encyclopedia of Government and Politics (Vol. 1). London: Routledge.

in text citation : (Graycar, 1992)

\section{Interview}

Sultan Hamengkubuwono X (interview, 2011, April 19)

in text citation: (Hamengkubuwono, 2011)

\section{Documentary film}

Steijlen, Fridus (2008). A Day in the Life of Indonesia [documentary film, 58 minutes]. Leiden: KITLV Press.

in text citation : (Steijlen, 2008) 
Vol. 3 No. 2, May - August 2018 